\title{
Characterization of Metallurgical Coke Produced with Coal Mixtures and Waste Tires
}

\author{
Guilherme Liziero Ruggio da Silva ${ }^{a,}$, Renata Dias Silva ${ }^{a^{*},}$ Leticia Cheloni ${ }^{b}$, \\ Victor Eric de Souza Moreira ${ }^{c}$, Natália Brasil Dias Haneiko ${ }^{c}$, Paulo Santos Assis ${ }^{a, b}$ \\ ${ }^{a}$ Rede Temática em Engenharia de Materiais - REDEMAT, Praça Tiradentes, 20, \\ Centro, Ouro Preto, MG, Brazil \\ ${ }^{b}$ Departamento de Engenharia Metalúrgica e de Materiais, Universidade Federal de Ouro Preto - \\ UFOP, Campus do Morro do Cruzeiro, Bauxita, Ouro Preto, MG, Brazil \\ ${ }^{c}$ Departamento de Engenharia Metalúrgica, Instituto Federal de Minas Gerais - IFMG, Campus Ouro \\ Branco, Afonso Sardinha, 90, Pioneiros, Ouro Branco, MG, Brazil
}

Received: December 5, 2015; Accepted: April 13, 2016

\begin{abstract}
The use of scrap tires in the coal blends is an alternative to reduction of coke production costs as well as mitigates the impact caused by tire accumulation in the environment. Tests were carried out on a pilot scale, with coal blends and waste tire in 4 levels and 3 particle sizes, in order to assess the impact on the produced coke quality, especially on the Strength after Reaction with $\mathrm{CO}_{2}-\mathrm{CSR}$ and Drum Index (DI150-15). In addition, it evaluated the mechanical resistance to compression, punctual chemical composition by Energy Dispersive Spectroscopy (EDS) analysis beyond the carbonaceous matrix-tire interface by SEM microscopy. The results from the coking tests showed that addition of up to $3 \%$ of the average ground tire $(20-30 \mathrm{~mm})$ with steel mesh, raised either as CSR DI150-15, making feasible added also from a technical point of view.
\end{abstract}

Keywords: Coke, Coal, Waste Tire, Resistance

\section{Introduction}

The mineral coal used in Integrated Coke Plants, burdens the steel production cost in 30 to $40 \%{ }^{1,2}$. Therefore, the Brazilian steel competitiveness in the international market depends on the decrease in the coke production costs. A feasible way to reduce this cost is to use alternative materials, which are coal cheaper, but which are capable of maintaining the coke quality required by blast furnaces. Following this context, the new raw materials addition added to the carbonaceous coal blends for the metallurgical coke production is a viable route, and the waste tire a promising material ${ }^{3}$.

The use of recyclable polymers such as tire in steel reactors, being decomposed compatibly metallurgical process, is already used by an alternative Germany, Japan and Belgium. It used as a partial replacement of the coke used in Electric Arc Furnaces (FEA) $)^{4,5,6}$. Fernandez et. all in their study concluded that the rubber tire addition ( $\operatorname{size}<3 \mathrm{~mm}$ ), in the coal blends decreases the mechanical strength of coke, especially DI $150-158^{3}$.

The waste tire used as an additive in coal blends for metallurgical coke production can be considered based on his constitution of natural rubber and synthetic elastomers with carbon black addition, which provides the material about $70 \%$ carbon, which resembles and qualifies its use as carbonaceous raw materials ${ }^{5}$. It is also composed of a steel structure arranged between the rubber layers introducing

*e-mail: renata.diasss@hotmail.com about $20 \%$ of iron. The typical tire chemical composition is shown in table 1 .

The waste tire recycling is necessary because of the increasing volume, generating large environmental impact upon their improper disposal. In Brazil, after the creation of the Resolution CONAMA 416/09 determining the manufacturer and importers of new tires, weighing more than two kilos the unit to collect and properly intended five scrap tires for every four new tires placed on the domestic market, energy potential that the tire is has been further explored in order to suppress the material volume disposed in the environment ${ }^{8,9}$. The Brazilian tire sale can be seen in the graph of figure 1 .

According Andrietta, the irregular disposal of tires is considered an aggressive allocation to the environment because of biodegradation long time and toxic substances release into the environment during this process, and has low ignition temperature where its burning produces toxic gases and black smoke from the fuel oil present in his composition?

The use of ground tire in the coal blends for metallurgical coke production can be considered an environmentally friendly destination because all the gases from the process are collected, treated and reused ${ }^{11}$.

The present study evaluates the impacts of tire addition in different particle size and levels on the coke produced quality in order to identify the best waste tire addition setting to the coal blends. 


\section{Experimental}

\subsection{Materials}

For the coking coal blends were used base (BB), supplied from a Brazilian steel company with relevance physicchemical parameters obtained through immediate analysis performed upon receipt according to table 2 .

These BB were added waste tires supplied by Brazilian Recycler, in three different grain sizes: Thin Tire (TT) constituted only by rubber and a particle size of up to $5 \mathrm{~mm}$, Medium Tire (MT) consisting of the raw tire with a diameter of 20-30 mm and Gross Tire (GT) also consists of unprocessed tire with a diameter of 50-100 mm.

The rubber tire immediate analyses performed upon receipt the samples and waste tire base chemical composition is shown in table 3 and $4^{12}$.

\subsection{Scale Pilot Production}

Initially the blends were prepared, using coal with a particle size $85 \%$ less than 2.83 being added to each type of tire (TT, MT, GT) in weight percentages of 1, 3, 5 and 10\%, and then homogenized by the conical cells method. A sample containing only $\mathrm{BB}$ was used for comparison.

They used loads of $200 \mathrm{~kg}$ coal-tire blends, heated to $1000^{\circ} \mathrm{C}$ in an Electric Furnace Pilot. After the coking time, the coke produced was extinguished in water. Samples of $80 \mathrm{~kg}$ were collected to perform the analyses of interest.

\subsection{Characterization}

Immediate Analysis was performed of coke produced samples, and the ash chemical composition was obtained by the Atomic Absorption method. Also coke strength analyses

Table 1. Base chemical composition of tire types $(\%)^{7}$.

\begin{tabular}{ccccccc}
\hline & $\mathbf{C}$ & $\mathbf{F e}$ & $\mathbf{Z n}$ & $\mathbf{S}$ & $\mathbf{H}$ & Others \\
\hline Tire & 70 & 15 & 1,2 & 1,3 & 7 & 5,5 \\
\hline
\end{tabular}

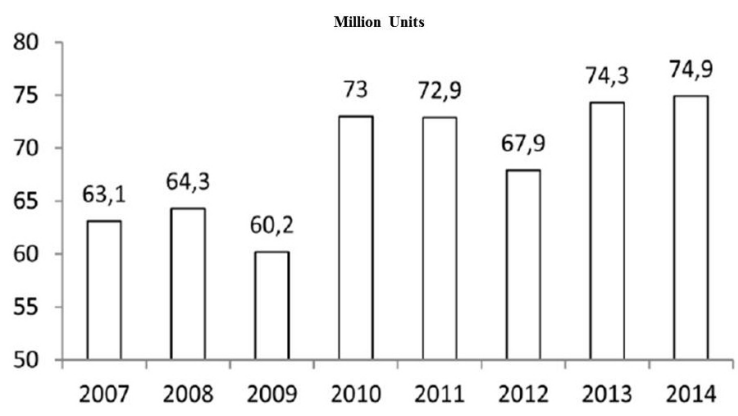

Figure 1. Tire amount sold 2007-201410. were performed by CSR, CRI according to the methodology of Nipon Steel Company (NSC) and DI150-15.

Five sub-samples of each coke class were selected with a grain size of 19-21 mm, for morphology and interfaces tire / coke observation by Scanning Electron Microscopy (SEM) coupled with the punctual chemical composition by Energy Dispersive Spectroscopy (EDS).

Compression tests were performed in order to measure the maximum force applied to the material to initiate the breaking process.

\section{Results and Discussions}

\subsection{Visual Inspection Coke}

The coke produced from the addition of MT and GT unprocessed showed three distinct behaviors of interaction between the steel structure and carbonaceous matrix, due to the steel presence contained: i) steel mesh located inside the coke particles, ii) cokes with steel mesh outcrop and iii) cokes interconnected by steel mesh. Figure 2 shows a model of the three characteristics.

It was observed that composites formed from coke / steel having high mechanical strength, since the mesh acts as a structural coke agent.

\subsection{Immediate Analysis}

Figure 3 shows the Ash and \%Sulfur in the coke according to the \% Tire in the blends.

It is noted that the ash concentrations in the coke with tire addition are less than the coal base blends and the ash in coke with MT were smaller than mixtures TT and GT. Since TT is composed only of the rubber tire by the ash content tends to be lower.

In contrast, it is noted that all samples with tire had higher sulfur concentration compared with the basic coke produced with $\mathrm{BB}$, which was expected because the tire has an average of $2.2 \%$ sulfur in rubber to $0.81 \%$ sulfur coal base used. This behavior is more prominent in addition to TT compared MT and GT, because the sulfur is present in the rubber vulcanization process due to that used to increase rubber strength ${ }^{12,13}$.

\subsection{CSR, CRI, DI}

Figure 4 illustrates the variance analysis (ANOVA), to evaluate the tire addition impacts on DI150-15 and CSR.

The ANOVA showed that both the grain size as the tire level addition is relevant to the parameters evaluated.

Regarding DI150-15, in figure 5 we can observe a sharp decline with this parameter increase in TT addition, since the rubber is very fluid and is responsible for increasing the coke porosity and consequently decrease in mechanical

Table 2. Physic-chemical characterization of coal based blends.

\begin{tabular}{|c|c|c|c|c|c|c|}
\hline VM (\%) & Ash (\%) & S (\%) & $\begin{array}{l}\text { Fluidity log } \\
\text { (ddpm) }\end{array}$ & $\begin{array}{l}\text { Reflectance } \\
\text { (\% reflected) }\end{array}$ & Vitrinite (\%) & \\
\hline 23,46 & 6,97 & 0,81 & 2,6 & 1,12 & 62,2 & \\
\hline $\mathrm{SiO}_{2}(\%)$ & $\mathrm{Al}_{2} \mathrm{O}_{3}(\%)$ & $\mathrm{Fe}_{2} \mathrm{O}_{3}(\%)$ & $\mathrm{CaO}(\%)$ & $\mathrm{K}_{2} \mathrm{O}(\%)$ & $\mathrm{Na}_{2} \mathrm{O}(\%)$ & $\operatorname{MgO}(\%)$ \\
\hline 52,38 & 33,31 & 8,13 & 2,69 & 1,29 & 0,32 & 1,45 \\
\hline
\end{tabular}


strength. On the other hand, the MT and GT for containing steel structure, to generate cokes DI150-15's greater than the basic coke produced with only BB, since the steel structure acts as structural element, reducing crack propagation, are more effective interaction with MT the carbonaceous matrix.

In relation to the CSR, by increasing tire percentage in the mixture, there is loss for all types and addition levels other than MT with 3\% added, which kept the CSR levels close to those observed in the baseline coking, thus as can be seen in figure 6 .

\subsection{Compressive Strenght}

The results of the compressive strength test are shown in figure 7.

Table 3. Chemical composition of the tire rubber.

\begin{tabular}{cccc}
\hline Ash (\%) & VM (\%) & $\mathbf{C}_{\text {fix }}(\mathbf{\%})$ & $\mathbf{S ~ ( \% )}$ \\
\hline 4,0 & 48,5 & 47,5 & 2,2 \\
\hline
\end{tabular}

Table 4. Typical tire chemical composition in $\%$ mass $^{5}$.

\begin{tabular}{lccccccc}
\hline \multicolumn{1}{c}{ PNEU } & $\mathbf{C}$ & $\mathbf{H}$ & $\mathbf{O}$ & $\mathbf{N}$ & $\mathbf{S}$ & $\mathbf{F e}$ & $\mathbf{Z n}$ \\
\hline CARRO & 71 & 7 & 4 & 0,5 & 1 & 15,5 & 1 \\
CAMINHÃO & 62 & 6 & 3 & 0,5 & 1 & 25,5 & 2 \\
\hline
\end{tabular}

Note that if the compressive strength containing coals blends and MT $1 \%$ and 3\% were near the BB and blends with TT and GT addition were always below the BB. These results confirm the results of DI150-15 in which we observed the best interaction between the MT and the coke carbonaceous matrix.

\subsection{SEM and EDS}

Figure 8 shows the coke micrographs with MT addition, which can be observed the interface steel structure motherboard coke.

Highlighted the interaction between the steel structure and the matrix where we did not observe the pores formation and dullness cracks in the interface, which reinforces the argument that the mesh contributes to positive contribution of composite formation in strength when added up to $3 \%$.

The specific analysis via EDS demonstrated the coke presence in the steel matrix, as can be seen in figure 9 .

The analysis shows the basic components presence of low carbon steel commonly used as structural reinforcement in tires. In carbonaceous matrix having about $98 \%$ carbons as expected, and can also be found others inherent element of the tire that are not removed by coking process or others process factors.
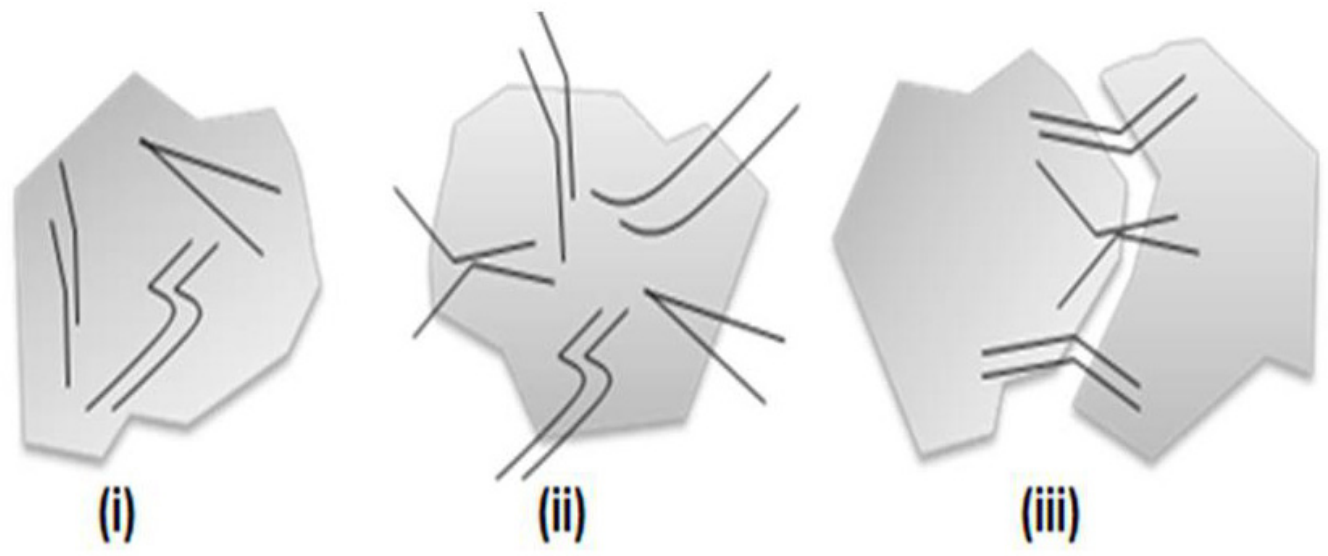

Figure 2. Types of interactions between the steel structure and coke matrix.
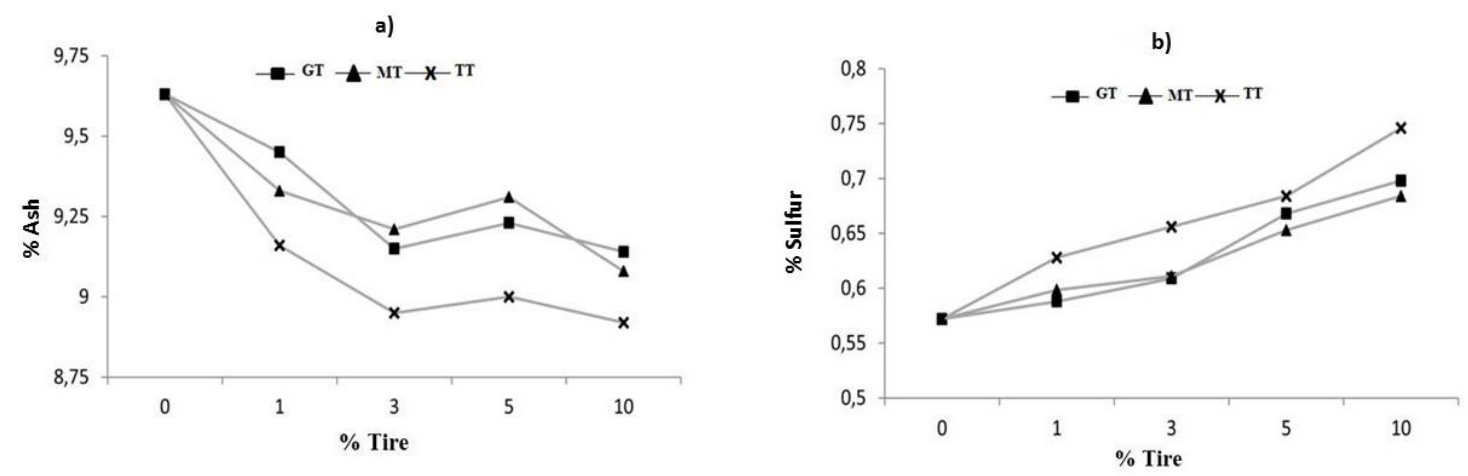

Figure 3. Analysis of ash and sulfur coke. 
Variance Analyses: DI versus \%; Grain Size

$\begin{array}{llrl}\text { Factor } & \text { Type } & \text { Levels } & \text { Values } \\ \delta & \text { fixed } & 4 & 1 ; 3 ; 5 ; 10 \\ \text { Granulometria } & \text { fixed } & 3 & \text { Fino; Grosso; Médio }\end{array}$

Analysis of Variance for DI, using Adjusted SS for Tests

$\begin{array}{lrrrrrr}\text { Source } & \text { DF } & \text { Seq SS } & \text { Adj SS } & \text { Adj MS } & \text { F } & \text { P } \\ \text { o } & 3 & 125,898 & 125,898 & 41,966 & 11,51 & 0,000 \\ \text { Granulometria } & 2 & 283,803 & 283,803 & 141,901 & 38,92 & 0,000 \\ \text { Error } & 18 & 65,624 & 65,624 & 3,646 & & \\ \text { Total } & 23 & 475,325 & & & & \end{array}$

Variance Analyses: CSR versus \%; Grain Size

$\begin{array}{llrl}\text { Factor } & \text { Type } & \text { Levels Values } \\ \text { के } & \text { fixed } & 4 & 1 ; 3 ; 5 ; 10 \\ \text { Granulometria } & \text { fixed } & 3 & \text { Fino; Grosso; Médio }\end{array}$

Analysis of Variance for CSR, using Adjusted SS for Tests

$\begin{array}{lrrrrrr}\text { Source } & \text { DF } & \text { Seq SS } & \text { Adj SS } & \text { Adj MS } & \text { F } & \text { P } \\ \text { \& } & 3 & 403,72 & 403,72 & 134,57 & 18,22 & 0,000 \\ \text { Granulometria } & 2 & 627,85 & 627,85 & 313,92 & 42,50 & 0,000 \\ \text { Error } & 18 & 132,97 & 132,97 & 7,39 & & \\ \text { Total } & 23 & 1164,53 & & & & \end{array}$

$S=2,71789 \quad \mathrm{R}-\mathrm{Sq}=88,58 \frac{8}{8} \quad \mathrm{R}-\mathrm{Sq}(\mathrm{adj})=85,41 \frac{8}{8}$

Figure 4. The particle size variance analysis relative to DI150-15 and CSR.

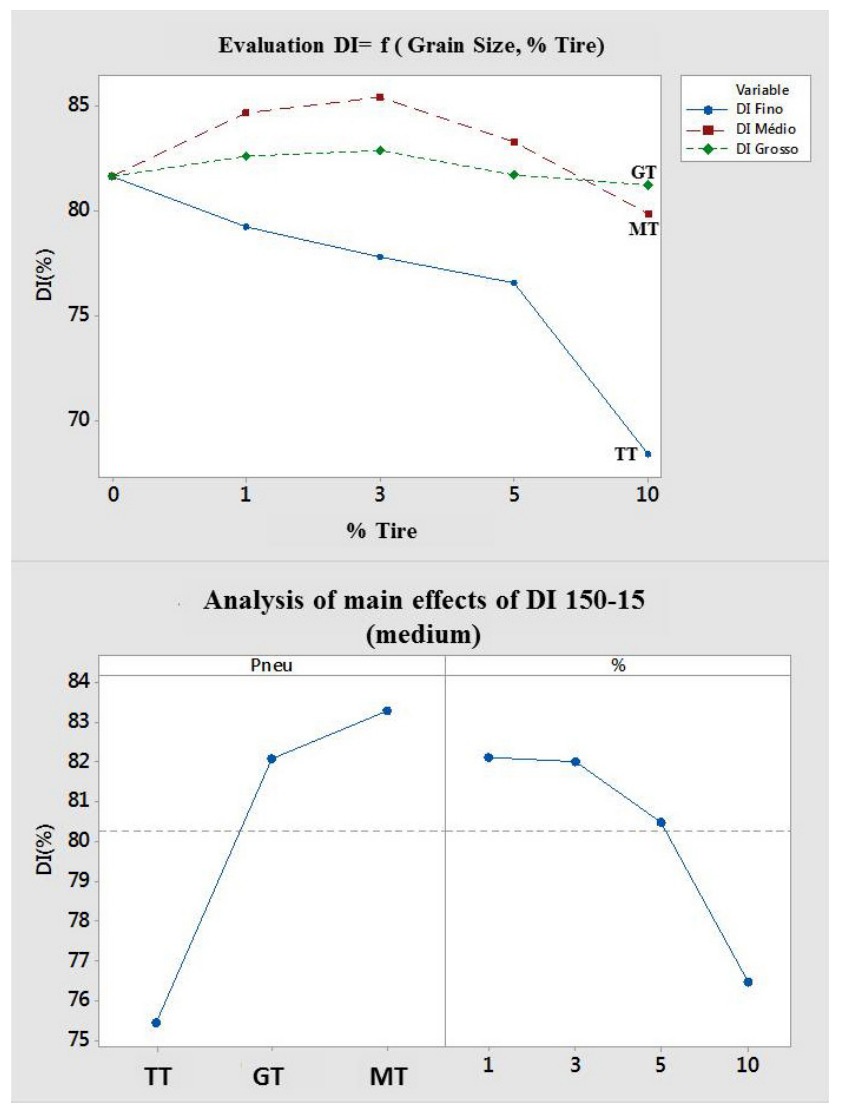

Figure 5. Variation of DI 150-15 coke regarding the percentages and tires types. 


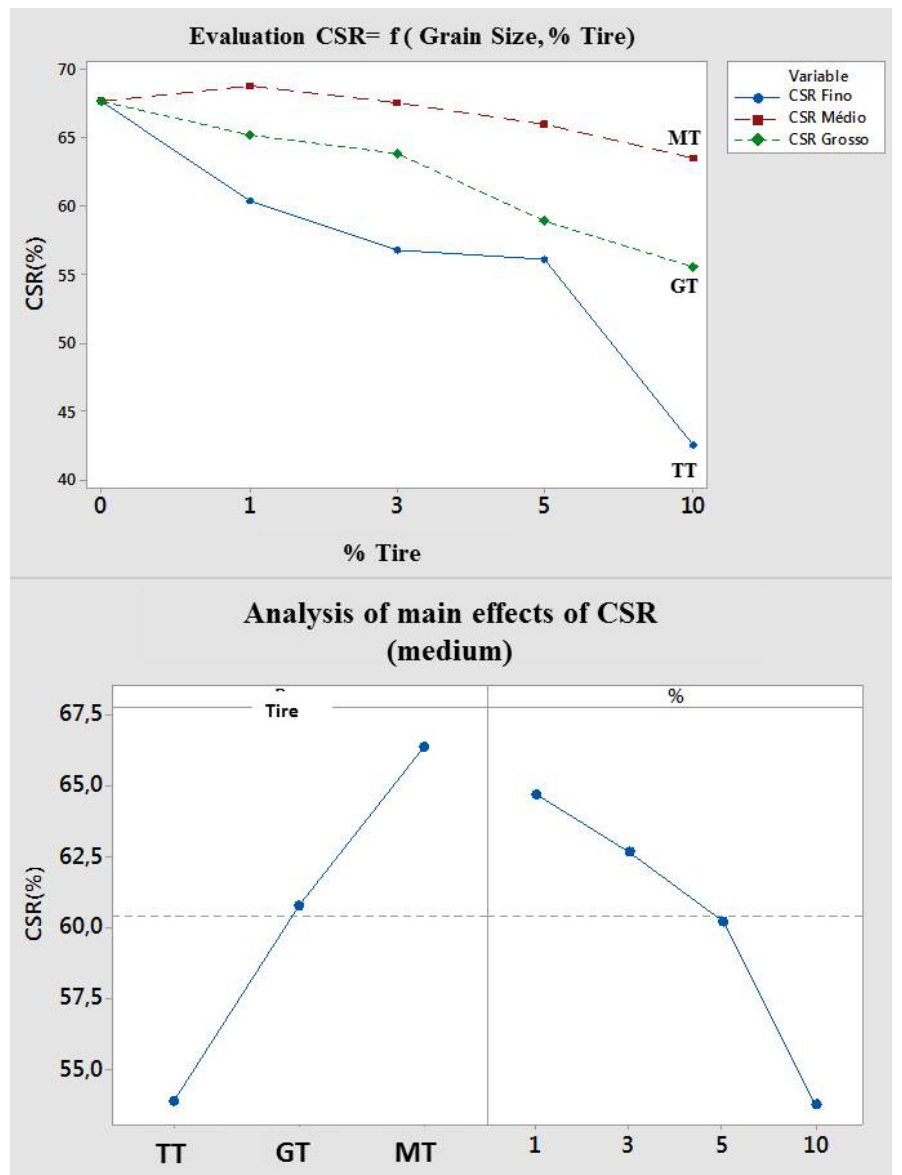

Figure 6. Variation of CSR coke regarding the percentages and types of tires.

\section{Compressive Strength}

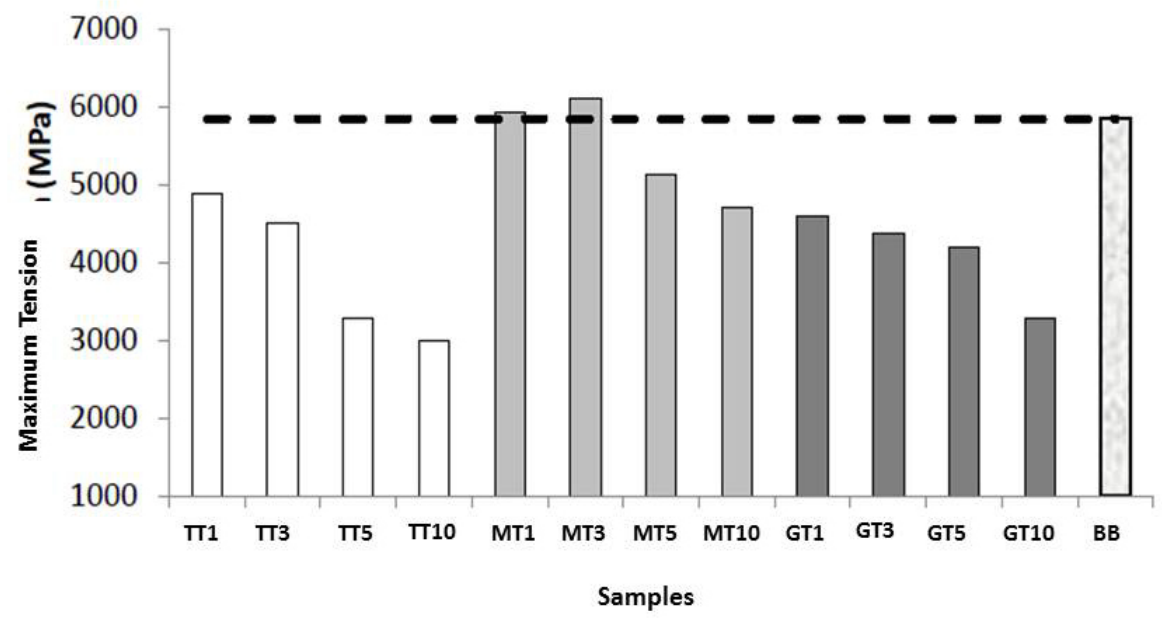

Figure 7. Maximum tension values of each sample. 

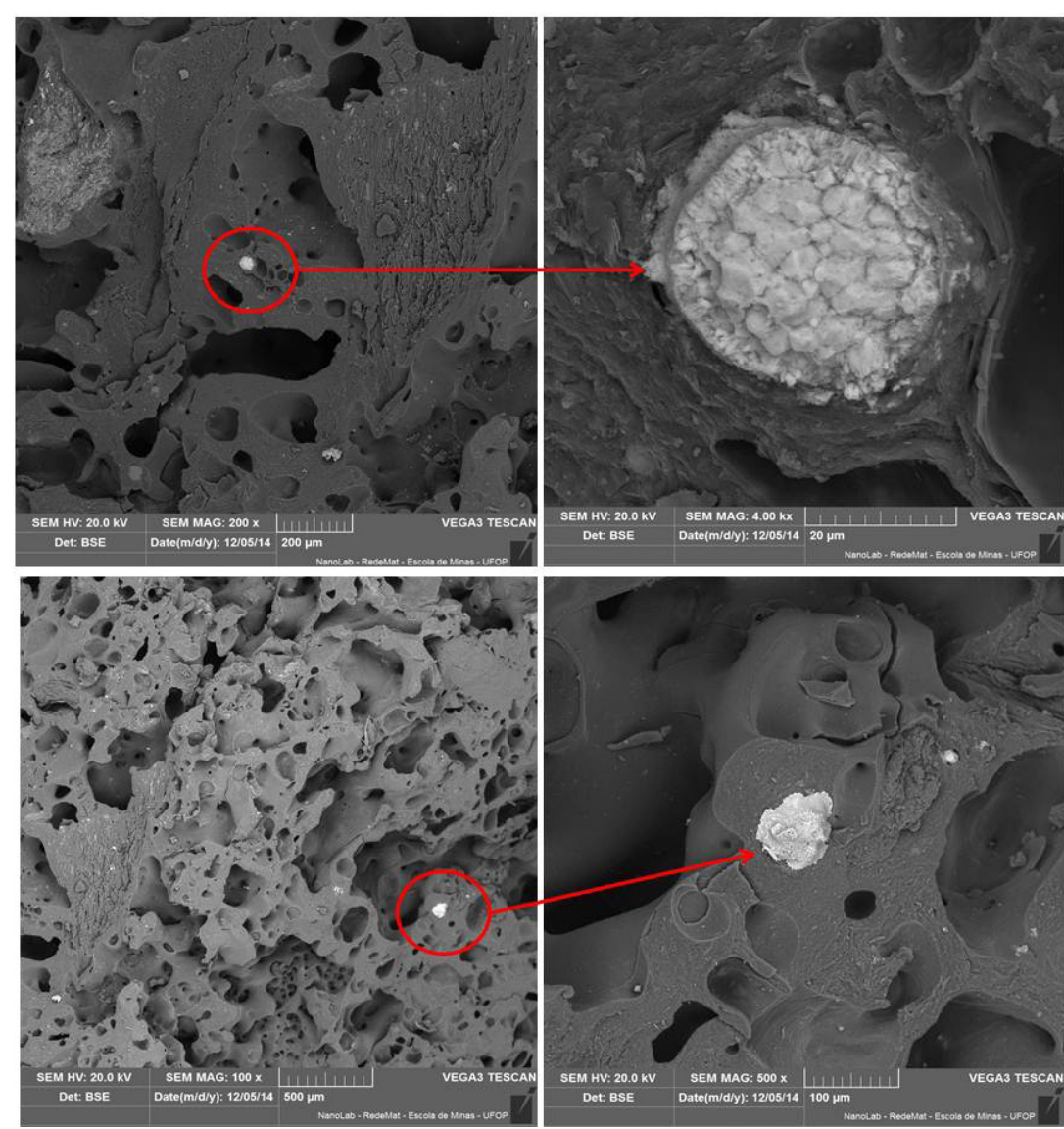

Figure 8. Scanning Electron Microscopy coke with steel mesh to eat coke condition of MT 3\%.

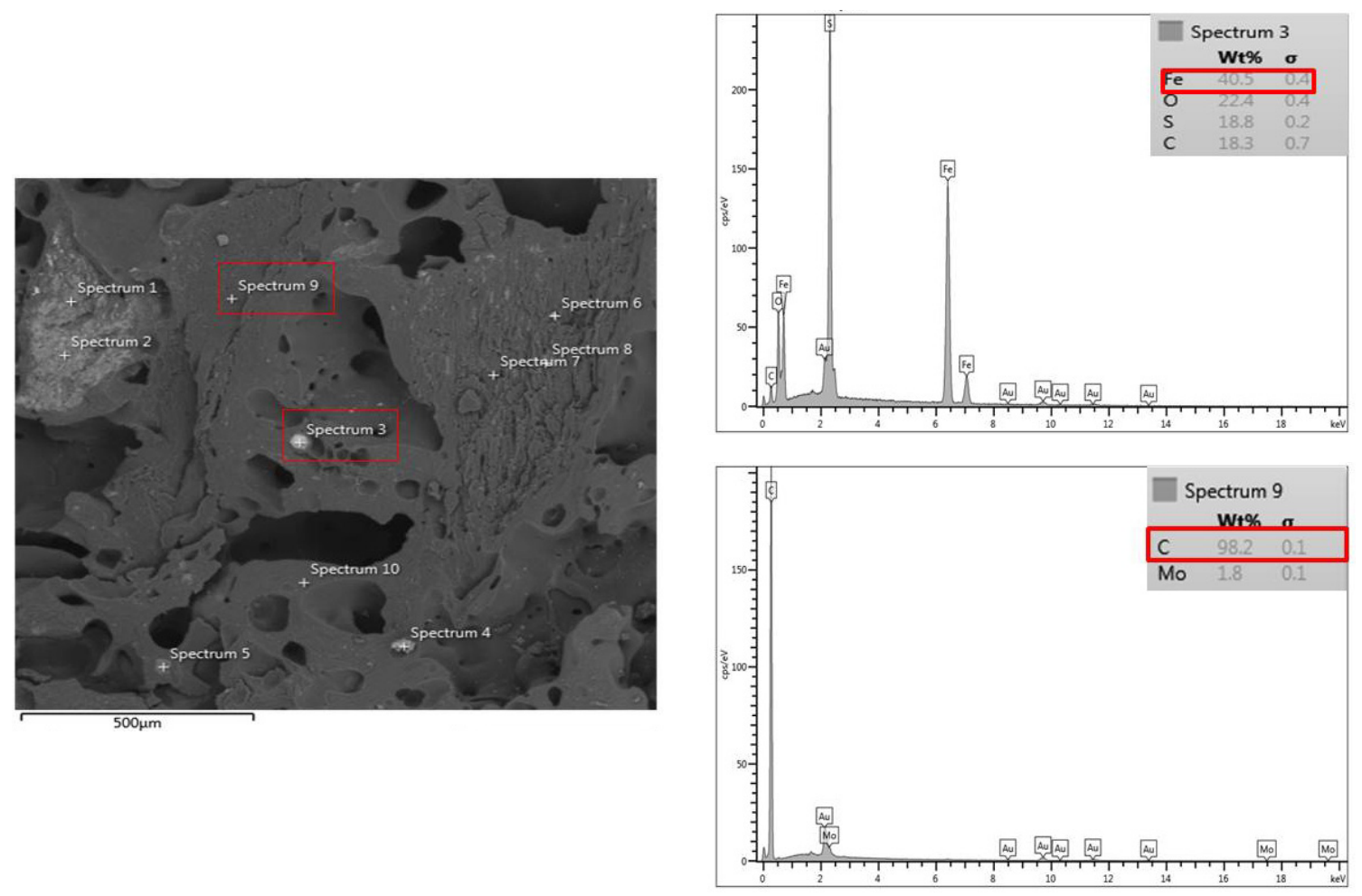

Figure 9. EDS analysis of coke with steel mesh to eat coke condition of MT 3\%. 


\section{Conclusions}

The characterization of metallurgical coke produced with waste tires addiction showed that have higher sulfur content and lower ash concentrations when compared to the coke produced only by coals blends. The best results relative to DI150-15 and CSR were obtained with the use of the tire up to $3 \%$ in average particle size $(20-30 \mathrm{~mm})$ due to the tire steel structure presence, which interacts with the carbonaceous matrix, acting as structural coke agent.

The waste tire use in coal blends for producing coking coal is configured as a viable alternative, as the main coke quality characteristics can be maintained. The reduced coke

\section{References}

1. Silva OJ. Caracterização tecnológica de carvões para coqueria [Dissertation]. Federal University of Ouro Preto. Rede Temática em Engenharia de Materiais; 2008.

2. Coelho RJ, Silva OJ, Alves MT, Andrade LA, Assis PS. Modelos de previsão da qualidade metalúrgica do coque a partir da qualidade dos carvões individuais e do coque obtido no forno-piloto de coqueificação. Revista Escola de Minas. 2004;57(1):27-32. http://dx.doi.org/10.1590/S0370-44672004000100006

3. Fernández AM, Barriocanal C, Gupta S, French D. Effect of Belnding Carbon-Bearing Waste with Coalo n Mineralogy and Reactivity Cokes. Journal Energy \& Fuels. 2014;28(1):291-298. http://dx.doi.org/10.1021/ef401268f

4. Zaharia M, Sahajwalla V, Kim BC, Khanna R, Saha-Chaudhury N, O'Kane P, et al. Recycling of Rubber Tires in Electric Arc Furnace Steelmaking: Simultaneous Combustion of Metallurgical Coke and Rubber Tyres Blends. Journal Energy \& Fuels. 2009;23(5):2467-2474. http://dx.doi.org/10.1021/ ef8010788

5. Ayed P, Clauzade C, Gros B, Huber JC, Lebrun C, Vassart N. Charging used tyres in the EAF, as a substitute for carbon: a success story for LME and Industeel Belgium. Metallurgy Review. 2007;104(3):128-135. http://dx.doi.org/10.1051/ metal:2007101

6. Gorni A. Aproveitamento de sucata de pneus e resinas plásticas em fornos elétricos a arco. In: IV PlastShow; 2008 May 6-8; production cost due to lower value of waste tires in relation to coal, is another factor that stimulates this alternative, extend beyond route to use this kind of material thus reducing environmental impact.

\section{Acknowledgements}

Thematic Network of Materials Engineering REDEMAT

Federal University of Ouro Preto - UFOP

Gerdau Ouro Branco

Federal Institute of Minas Gerais - Campus IFMG Ouro Branco

São Paulo; 2008. Available from: http://www.gorni.eng.br/ Gorni_PlastShow_Mai2008.pdf

7. Andrietta AJ. Pneus e meio ambiente: um grande problema requer uma grande solução [Internet]. [cited 2014 Jan]. Available from: http://pt.scribd.com/doc/15706935/Pneus-e-Meio-Ambiente.

8. GORNIA. As Siderúrgicas São o Novo Espaço para a Reciclagem Energética de Plásticos Pós- Consumo. Plástico Industrial. 2006;8(89):84-100.

9. IBAMA. Instituto Brasileiro de Meio Ambiente e dos Recursos Naturais Renováveis. Relatório de Pneumáticos: dados apresentados no Relatório de Pneumáticos relativos ao ano de 2012. Resolução CONAMA n ${ }^{\circ}$ 416/2009”, IBAMA: Brasília; 2013.

10. Associação Nacional da Indústria de Pneumáticos - ANIP. Departamento de Estudos. Relatório de Produção e Vendas 2014 [Internet]. [cited 2015 Mar]. Available from: http://www. anip.com.br/arquivos/producao_vendas.pdf

11. Gardin JAC, Figueiró PS, Nascimento LF. Logística reversa de pneus inservíveis: Discussões sobre três alternativas de reciclagem para este passivo ambiental. Journal Gestão e Planejamento. 2010;11(2):232-249.

12. Ignatz-Hoover F, To BH. Rubber compounding: chemistry and applications. New York: Marcel Dekker; 2004.

13. De D and De D. Processing and material characteristics of a reclaimed ground rubber tire reinforced styrene butadiene rubber. Materials Sciences and Applications. 2011;2(5):486495. http://dx.doi.org/10.4236/msa.2011.25066. 